\title{
Relationship between Hidrogenionic Potential (pH) of Protein-based Baits and Attraction of the Mediterranean Fruit Fly, Ceratitis capitata (Wiedemann)
}

\author{
N. M. GHANIM* and M. M. EL-METWALLY \\ Plant Protection Research Institute, Agricultural Research Center, Dokki, Giza, Egypt
}

(Received: 26 July 2018; accepted: 3 September 2018)

\begin{abstract}
Hidrogenionic potential $(\mathrm{pH})$ of the baits plays a fundamental role in attracting fruit flies. So, the purposes of this study were to study the effect of $\mathrm{pH}$-level on the ability of protein-based baits to attract Mediterranean fruit fly, Ceratitis capitata (Wiedemann) (Diptera: Tephritidae) under field conditions. Three concentrations of Buminal $(2.5,5$ and $10 \%)$ in addition to three concentrations of ammonium acetate, ammonium carbonate, di-ammonium phosphate and acetic acid (1,2 and 3\%) added to Buminal 5\% were tested by using the modified Nadel traps in navel orange and mandarin orchards. The obtained data showed that the highest effective treatment in attracting C. capitata adults in navel orange and mandarin orchards was that of Buminal $+3 \%$ of ammonium acetate, where, $\mathrm{pH}$-levels ranged between 6.32 and 6.89 . Buminal + acetic acid when used at pH-levels ranged between 3.73 and 4.43 were less attractive to $C$. capitata. All of the tested treatments obviously attracted females more than males. Statistically, $C$. capitata adults specifically were females affected by $\mathrm{pH}-$ level more than concentration percentage. C. capitata preferred baits which had $\mathrm{pH}$-levels ranged between 5.5 and 8.5 and the highest attractive treatments were occurred between 6.32 and 8.29.
\end{abstract}

Keywords: Hidrogenionic potential, Ceratitis capitata, attractants, insect traps, management, protein-based baits.

Mediterranean fruit fly, Ceratitis capitata (Wiedemann) (Diptera: Tephritidae) is a species of Afrotropical origin which has adapted to the climatic conditions of the Mediterranean basin (Franco et al., 2006). It is one of the most important pests destructing fruits of over 350 species of fruits, nuts and vegetables round the world (Liquido et al., 1991; White and Elson-Harris, 1992; Papadopoulos, 2014). In Egypt, the existence of hosts for C. capitata is the important reason to build up their generations; so, it occurred all over the year and increased during the fruiting seasons of the orchards (Hashem et al., 2001; Ghanim and Moustafa, 2009; Ghanim, 2012; Moustafa et al., 2014; Ghanim, 2016 and 2017). This pest causing a serious decline in both quantity and quality of fruit yield (Hassanein et al., 1995); whereas, its females lay their eggs inside fruits and the hatching maggots devour into the pulp and secondary infestations with bacterial and fungal diseases 
mostly exist and the infested fruits drop down and make fruits unfavorable for marketing and exportation (White and Elson-Harris, 1992; Borge and Basedow, 1997).

Tephritid fruit flies (including C. capitata) use chemical stimuli in the form of nutrients (Joachim-Bravo et al., 2001). Food sources which are rich in nitrogen have a strong influence on the physiology and behavior of tephritid flies (Kaspi et al., 2000; Yuval et al., 2007; Hemeida et al., 2017; El-Metwally, 2018). So, protein bait acts as food attractant and its effectiveness behaviorally relies on the fact that immature females need a protein meal to reach sexual maturity and for development of eggs to maturity (Epsky et al., 2014 and Pinero et al., 2015).

Protein bait sprays are more environmentally sound because of reduced pesticide usage, less risk of spray drift and less harmful to beneficial insects, making it suitable for use in IPM programs. Also, continuous monitoring of pest populations is of major component of IPM projects using traps (Barzman et al., 2015). So, optimizing trap attractants to improve detection of temporal and spatial trends is important in order to improve the efficacy of C. capitata control projects (Lance, 2014). According to Abd El-Kareim et al. (2008), Moustafa and Ghanim (2008), Ghanim et al. (2014) and Bayoumy and El-Metwally (2017), ammonia are associated with protein-rich foods and has long been known to attract fruit flies. So, Hemeida et al. (2017) and El-Metwally (2018) reported that protein-based baits can be enhanced by adding ammonia to them. Also, Yee and Landolt (2004) found that increasing the concentration of ammonia in lures significantly increased their attraction.

On the other hand, $\mathrm{pH}$-level of the baits plays a fundamental role in attracting fruit flies, since the effectiveness of bait is diminished as the $\mathrm{pH}$-level decreased (Heath et al., 1994; Rousse et al., 2005; El-Gendy, 2012 and 2013; Paiva and Parra, 2013; Hemeida et al., 2017: El-Metwally, 2018). Females of fruit flies are more responded to the increase of $\mathrm{pH}$-level more than males and $\mathrm{pH}$-level can be used in chemical analysis for identification of new attractants from preferred bait formulations (Hemeida et al., 2017; El-Metwally, 2018).

Therefore, the purposes of this study were to study the effect of hidrogenionic potential $(\mathrm{pH})$ on the ability of protein-based baits to attract $C$. capitata flies, and also to determine the range of $\mathrm{pH}$-levels which may be preferable for $C$. capitata under field conditions.

\section{Materials and Methods}

\section{Materials and treatments}

The commercial product of the protein-based bait, Buminal (hydrolyzed protein $39.78 \%$ ) was obtained from NABA GmbH company, Germany, and the four compounds of ammonium acetate $(\mathrm{AA})\left(\mathrm{CH}_{3} \mathrm{COONH}_{4}\right)$, ammonium carbonate $(\mathrm{AC})\left(\left(\mathrm{NH}_{4}\right) 2\right.$ $\left.\mathrm{CO}_{3}\right)$, di-ammonium phosphate (DAP) $\left(\left(\mathrm{NH}_{4}\right) 2 \mathrm{HPO}_{4}\right)$ and acetic acid Glacial (AcA) $\left(\mathrm{CH}_{3} \mathrm{COOH}\right)$ were obtained from El-Naser for Drugs and Chemicals Company.

Buminal was prepared at the three concentrations of 2.5, 5.0 and $10.0 \%$ ( $\mathrm{vol} / \mathrm{vol})$. Each of the other four compounds was added to Buminal (at the concentration of $5.0 \%$ ), at the three concentrations of 1.0, 2.0 and 3.0\%. Ammonium acetate, ammonium carbonate 
and di-ammonium phosphate were in solid state; so, they were added as wt/vol. Acetic acid was in liquid state; so, it was added as vol/vol.

\section{Field trials}

Experiments were conducted in navel orange, Citrus sinensis L. and repeated in mandarin, Citrus reticulata Blanco orchards belonging to the experimental farm of Mansoura University, Dakahlia governorate, Egypt. The selected areas were about eight feddans for each orchard specie $\left(1\right.$ feddan $\left.=4200 \mathrm{~m}^{2}\right)$. Experiments were carried out during the periods from the $25^{\text {th }}$ of December 2017 till the $6^{\text {th }}$ of January 2018 in navel orange orchard and from the $6^{\text {th }}$ till $18^{\text {th }}$ of January 2018 in mandarin orchard.

The modified Nadel traps (Hanafy et al., 2001) baited with the previously mentioned treatments were used. Each treatment consisted of 250 milliliters installed in a trap and replicated four times. Traps were distributed in a completely randomized design inside each orchard (navel orange or mandarin). Traps were hanged in a shaded place of the trees at a height of 1.5-2.0 meters above the ground. To avoid the interaction between lures, the distance between every two adjacent traps was about 40 meters.

Traps were inspected every three days (as intervals) for a period of 12 days after hanging. The captured flies of females and males were counted and recorded as FTDs (number of attracted flies per trap per day). The captured flies were removed from traps with no renewal of the bait solutions. Trap rotations were done every inspection to avoid the bias of fruit fly behavior linked with abiotic factors (i.e. light, wind, and heat).

\section{Estimating $\mathrm{pH}$ levels}

Fifty milliliters of each treatment were transferred to laboratory for estimating $\mathrm{pH}$ level. Samples were taken at the beginning of each inspection period (fresh bait and after 3,6 and 9 days) in navel orange and mandarin treatments. These samples were measured by Jenway $3510 \mathrm{pH}$ meter.

\section{Statistical analysis}

Data were analyzed by using one-way ANOVA followed by least significant difference (LSD) at probability level of 0.05 . Regression analysis was also performed. All analyses were performed using CoHort Software (2004).

\section{Results}

Data represented in Table 1 showed that the highest number of attracted females and males of $C$. capitata after 3 days (total FTD $=1.51$ and $1.50, F=4.47$ and $P<0.01$ ) in navel orange orchard were recorded when pH-levels at 7.71 (Buminal $5 \%+2 \% \mathrm{AC}$ ) and 7.76 (Buminal 5\%+2\%DAP). After $6(F=8.77$ and $P<0.01)$ and $9(F=8.06$ and $P<0.01)$ days, the highest number of attracted adults $(\mathrm{FTD}=2.67$ and 1.34$)$ was coincided with $\mathrm{pH}$ of 6.36 and 6.32 (Buminal $5 \%+3 \% \mathrm{AA}$ ). While, the highest number of attracted $C$. capitata after 12 days $(\mathrm{FTD}=0.42, F=0.89$ and $P=0.57)$ was recorded at 
pH-levels of 7.04 (Buminal 5\% + 1\%DAP), 7.25 (Buminal 5\%+1\%AC) and $8.61(\mathrm{Bu}-$ minal $5 \%+3 \% \mathrm{AC}$ ). In contrary, the lowest effective treatments in attracting C. capitata adults were generally those of Buminal 5\%+2\%AcA and Buminal 5\%+3\%AcA when pH-levels ranged between 3.73 and 4.25 .

In mandarin orchard (Table 2), Buminal 5\%+3\%AA was the highest treatment for attracting $C$. capitata adults after $3(\mathrm{FTD}=1.33, F=6.47$ and $P<0.01)$ and 6 days $(\mathrm{FTD}=1.75, F=4.06$ and $P<0.01)$ when $\mathrm{pH}$-levels of 6.70 and 6.51 , respectively. After 9 days, Buminal $5 \%+3 \%$ DAP $(\mathrm{pH}=7.04)$ attracted the highest numbers of $C$. capitata; whereas, FTD was $1.08(F=23.25$ and $P<0.01)$. With respect to Buminal $5 \%+1 \%$ AC, it was the highest attractive treatment to $C$. capitata adults after 12 days (FTD was 1.49, $F=3.39$ and $P<0.01$ ) when $\mathrm{pH}$ was 7.01 . As in navel orange experiment, Buminal $5 \%+2 \%$ AcA and Buminal 5\% +3\%AcA were the lowest effective treatments in attracting C. capitata adults in mandarin orchard; whereas, $\mathrm{pH}$-levels ranged between 3.87 and 4.07.

As shown in Fig. 1 and Tables 1 and 2, the highest effective treatment in attracting $C$. capitata adults in navel orange and mandarin orchards was that of Buminal $5 \%+3 \% \mathrm{AA}$ (pH-levels ranged between 6.32 and 6.89); whereas, the general means of

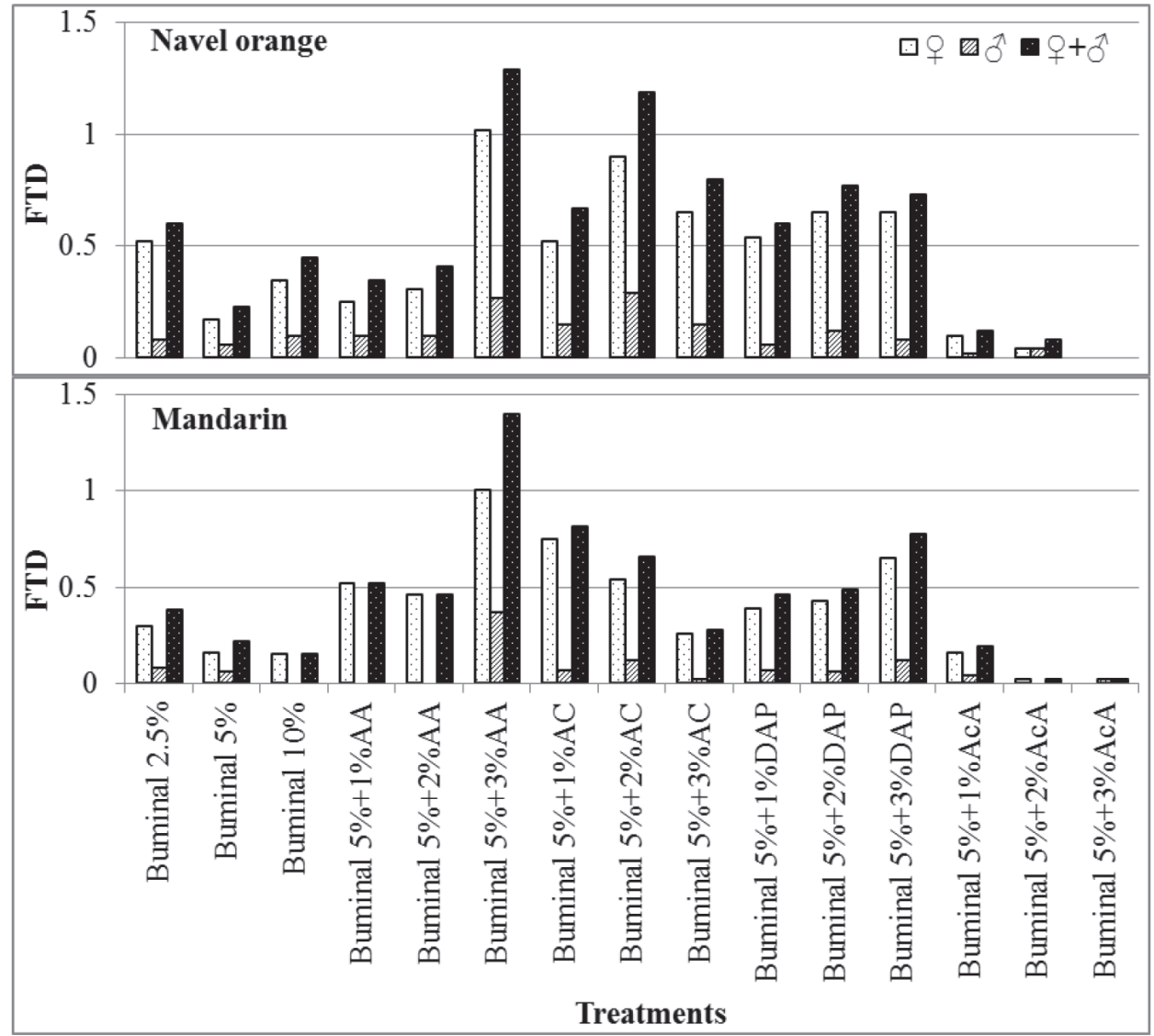

Fig. 1. Mean attracted C. capitata adults (females and males) to different preparations of Buminal all over the 12 days in navel orange and mandarin orchards at Dakahlia governorate, Egypt 


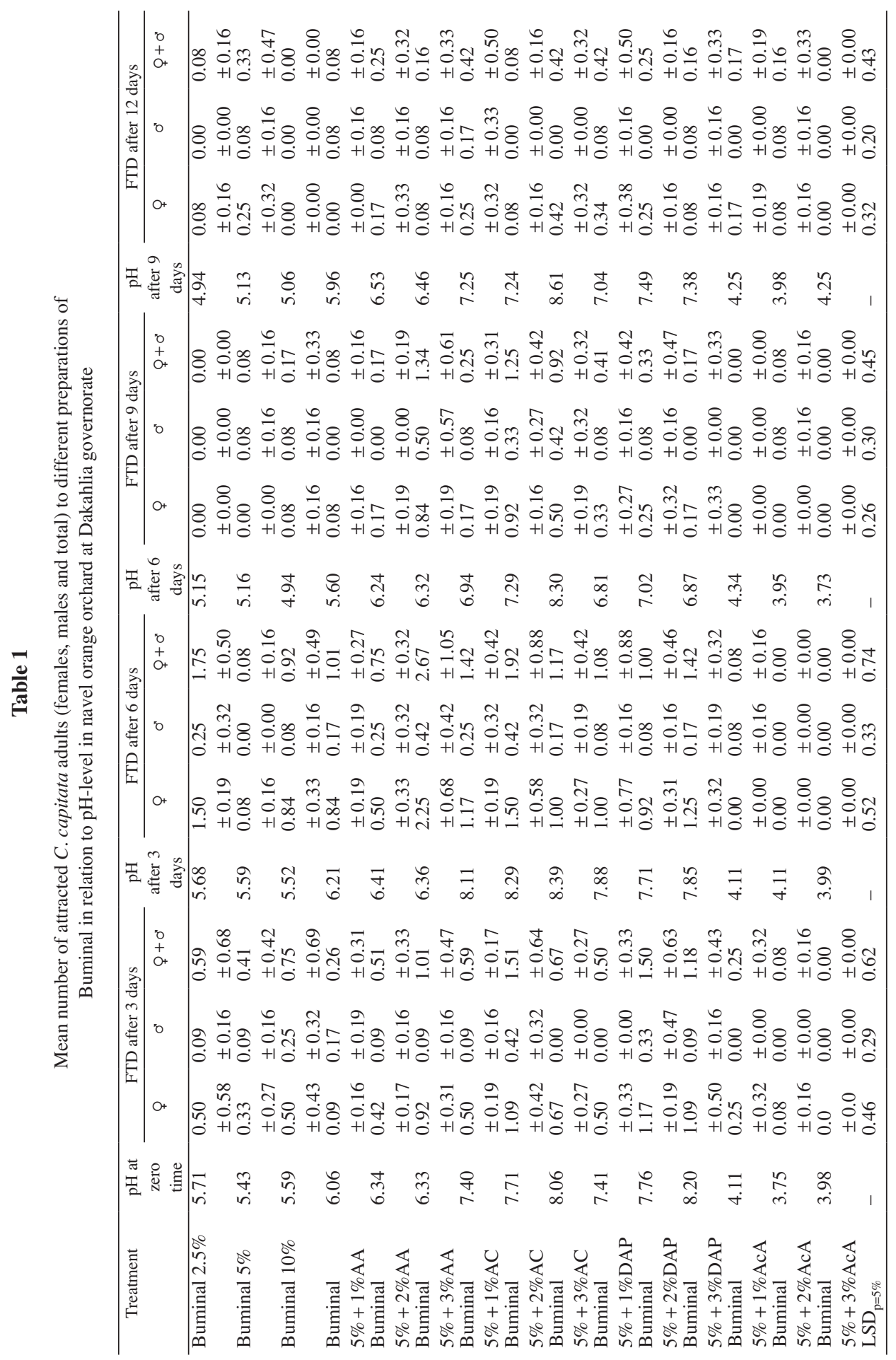




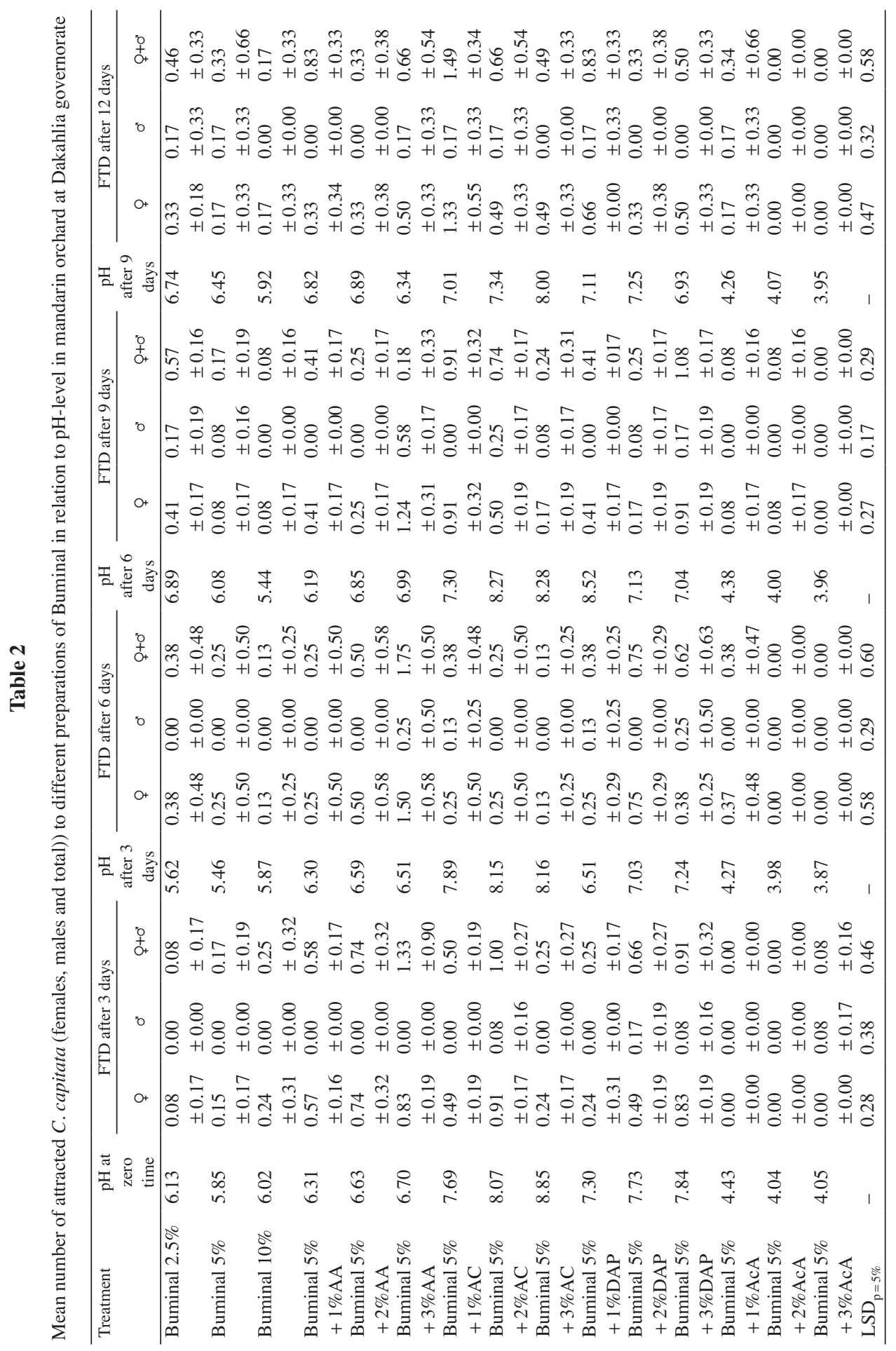


attracted flies (as total females and males) were 1.29 and 1.40, respectively. The second rank in navel orange was that of Buminal 5\% $+2 \% \mathrm{AC}(\mathrm{FTD}=1.19$ and $\mathrm{pH}$-levels ranged between 7.24 and 8.29) followed by Buminal 5\% $+3 \%$ AC (FTD $=0.80$ and pH-levels ranged between 8.06 and 8.61), Buminal 5\% +2\%DAP $(\mathrm{FTD}=0.77$ and pH-levels ranged between 7.02 and 7.76) and Buminal 5\% +3\%DAP (FTD $=0.73$ and pH-levels ranged between 6.87 and 8.20). In mandarin orchard, the second rank was that of Buminal $5 \%+1 \% \mathrm{AC}(\mathrm{FTD}=0.82$ and $\mathrm{pH}$-levels ranged between 6.34 and 6.99$)$ followed by $\mathrm{Bu}-$ minal 5\% +3\%DAP $(\mathrm{FTD}=0.78$ and $\mathrm{pH}$-levels ranged between7.03 and 7.73) and Buminal $5 \%+2 \% \mathrm{AC}(\mathrm{FTD}=0.66$ and $\mathrm{pH}$-levels ranged between 7.01 and 7.89). With respect to Buminal 5\%+2\%AcA and Buminal 5\%+3\%AcA treatments, mean FTDs all over the 12 days was relatively very low (ranged between 0.00 and 0.08 ) as well as pH-levels (ranged between 3.73 and 4.25).

On the other hand, all of the tested treatments attracted females obviously more than males in navel orange and mandarin orchards (Tables 1 and 2) and (Fig. 1).

Statistical analysis (Table 3 ) showed that attracted $C$. capitata (females, males and total adults) was affected by $\mathrm{pH}$-level more than concentration percentage of the tested compounds; whereas, regression coefficient values (b) in the relationships with pH-levels were higher than that with concentration percentages. For example, the highest b-value of $\mathrm{pH}$-levels in navel orange experiment was 1.21 (for Buminal alone) is offset by obviously low b-value of Buminal concentrations (-0.01). Also, the highest b-value of $\mathrm{pH}$-levels in mandarin experiment was that of Buminal $5 \%+\mathrm{AA}(0.41$ for females $)$ is offset by 0.26 .

Also, the determination coefficient $\left(\mathrm{R}^{2}\right)$ confirms these findings; whereas, $\mathrm{R}^{2}$-values of $\mathrm{pH}$-levels in navel orange experiment were higher than those of concentration percentages of Buminal alone, Buminal 5\% + AC and Buminal 5\%+DAP (Table 3). For

\section{Table 3}

Effect of $\mathrm{pH}-\mathrm{level}$ and concentration percentage of the tested compounds on the attracted C. capitata

(females, males and total adults) in navel orange and mandarin orchards at Dakahlia governorate

\begin{tabular}{|c|c|c|c|c|c|c|c|c|c|}
\hline \multirow[t]{3}{*}{ Compound } & \multirow[t]{3}{*}{ Sex } & \multicolumn{4}{|c|}{ Navel orange } & \multicolumn{4}{|c|}{ Mandarin } \\
\hline & & \multicolumn{2}{|c|}{ pH-level } & \multicolumn{2}{|c|}{ Concentration $\%$} & \multicolumn{2}{|c|}{ pH-level } & \multicolumn{2}{|c|}{ Concentration $\%$} \\
\hline & & $\mathrm{b}$ & $\mathrm{R}^{2}(\%)$ & $\mathrm{b}$ & $\mathrm{R}^{2}(\%)$ & $\mathrm{b}$ & $\mathrm{R}^{2}(\%)$ & $\mathrm{b}$ & $\mathrm{R}^{2}(\%)$ \\
\hline \multirow[t]{3}{*}{ Buminal alone } & Q & 1.04 & 45.8 & -0.01 & 1.0 & 0.10 & 15.5 & -0.02 & 22.0 \\
\hline & $0^{\prime \prime}$ & 0.17 & 31.1 & 0.003 & 1.4 & 0.14 & 75.6 & -0.01 & 24.1 \\
\hline & $Q+\sigma^{\prime \prime}$ & 1.21 & 46.0 & -0.01 & 0.4 & 0.22 & 45.2 & -0.03 & 31.7 \\
\hline \multirow{3}{*}{$\begin{array}{l}\text { AA } \\
\text { (in Buminal } 5 \%+\text { AA) }\end{array}$} & Q & 0.46 & 14.7 & 0.26 & 28.2 & 0.41 & 17.3 & 0.26 & 58.1 \\
\hline & $\sigma^{*}$ & 0.12 & 14.9 & 0.06 & 25.9 & 0.12 & 9.8 & 0.06 & 17.3 \\
\hline & $Q+\sigma^{\prime \prime}$ & 0.58 & 16.3 & 0.33 & 30.6 & 0.28 & 6.8 & 0.22 & 0.32 \\
\hline \multirow{3}{*}{$\begin{array}{l}\mathrm{AC} \\
\text { (in Buminal } 5 \%+\mathrm{AC} \text { ) }\end{array}$} & Q & 0.24 & 41.1 & 0.18 & 21.6 & 0.04 & 1.2 & 0.01 & 0.1 \\
\hline & $\sigma^{\prime \prime}$ & 0.05 & 16.5 & 0.04 & 8.6 & 0.002 & 0.1 & -0.01 & 1.1 \\
\hline & $Q+\sigma^{\prime \prime}$ & 0.29 & 38.0 & 0.22 & 20.0 & 0.04 & 1.1 & -0.001 & 0.00 \\
\hline \multirow{3}{*}{$\begin{array}{l}\text { DAP } \\
\text { (in Buminal 5\% + DAP) }\end{array}$} & Q & 0.29 & 48.7 & 0.16 & 17.4 & 0.16 & 22.6 & 0.15 & 46.4 \\
\hline & $\sigma^{*}$ & 0.02 & 6.6 & 0.01 & 3.5 & 0.01 & 1.0 & 0.02 & 5.6 \\
\hline & $O+\sigma^{\prime \prime}$ & 0.31 & 44.1 & 0.17 & 16.3 & 0.17 & 20.8 & 0.17 & 46.6 \\
\hline \multirow{3}{*}{$\begin{array}{l}\text { AcA } \\
\text { (in Buminal 5\% + AcA) }\end{array}$} & Q & 0.09 & 22.3 & -0.06 & 33.7 & 0.06 & 19.3 & -0.06 & 41.9 \\
\hline & $\sigma^{\prime \prime}$ & 0.02 & 13.4 & -0.02 & 22.4 & 0.03 & 19.5 & 0.02 & 10.5 \\
\hline & $O+\sigma^{*}$ & 0.11 & 27.4 & -0.07 & 43.0 & 0.09 & 30.9 & -0.08 & 45.6 \\
\hline
\end{tabular}


example, the highest determination coefficient value of $\mathrm{pH}-$ levels $(48.7 \%)$ was obtained with Buminal 5\% + DAP treatments on females is offset by low value of concentration percentages (17.4\%). With respect to Buminal 5\% + AA, the determination coefficient value of $\mathrm{pH}$-levels on the total adults in mandarin experiment $(6.8 \%)$ is offset by low value of concentration percentages $(0.32 \%)$. Buminal $5 \%+$ AcA treatments attracted obviously low numbers of $C$. capitata.

On the other hand, statistical analysis showed that females of $C$. capitata were generally more affected by $\mathrm{pH}$-levels and concentrations of the tested compounds in comparison with males. As shown in Table 3, both of regression coefficient values (b) and the determination coefficient $\left(\mathrm{R}^{2}\right)$ of females were higher than those of males in all of the tested compounds in navel orange experiment and most of them in mandarin experiment.

Figure 2 showed that $84.00 \%$ of the positive inspections which attracted females of $C$. capitata occurred between $\mathrm{pH}$-levels from 5.5 and 8.5. Less than $\mathrm{pH}$-level of 5.5, $13.00 \%$ of the positive inspections occurred; while, $3.00 \%$ occurred when $\mathrm{pH}$-level was more than 8.5 .

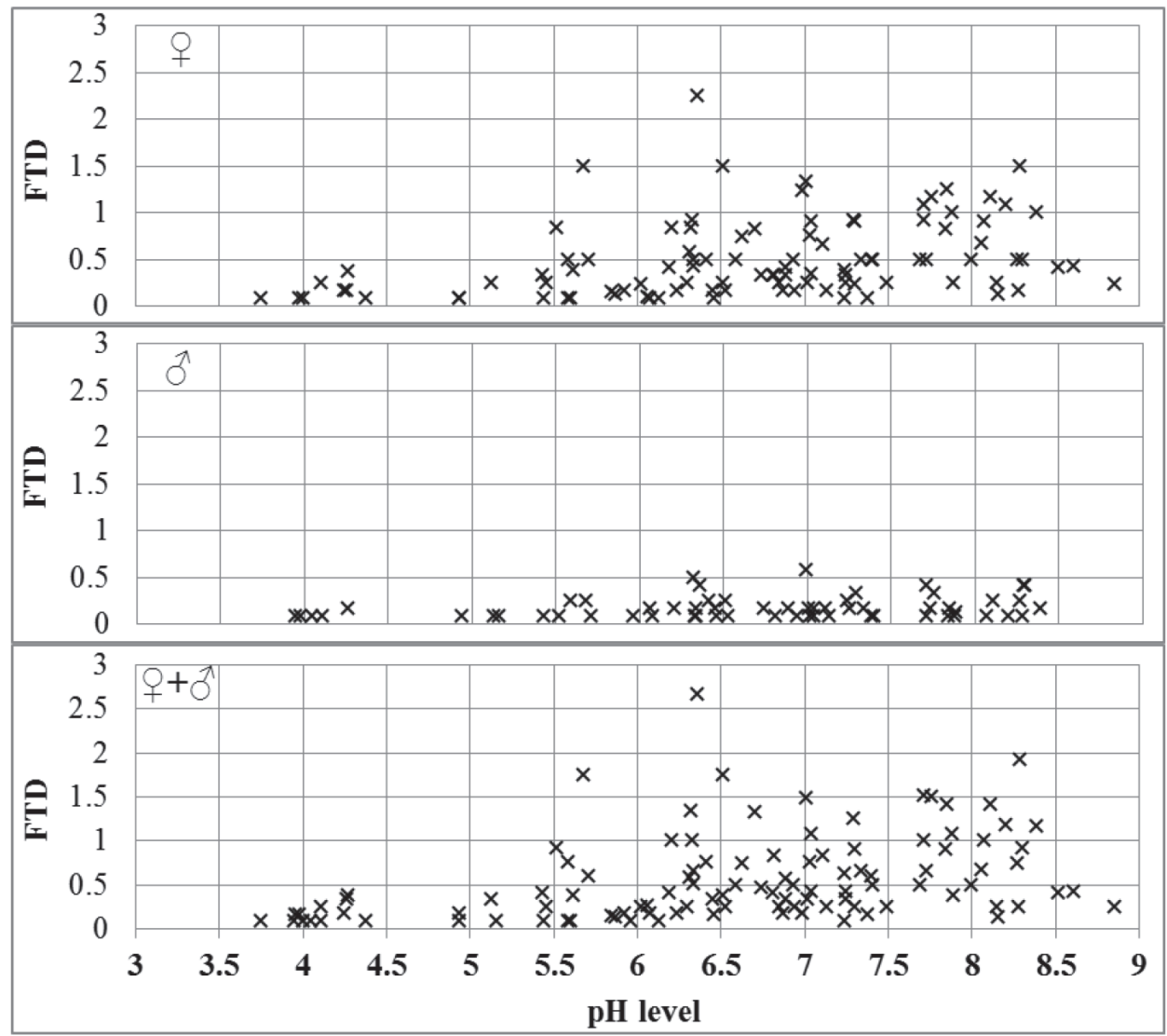

Fig. 2. Distribution of the positive traps (attracted C. capitata females, males and total adults as FTDs) within the range of $\mathrm{pH}$-levels in both of navel orange and mandarin experiments at Dakahlia governorate 
The levels of $\mathrm{pH}$ ranged between 5.5 and 8.5 had $85.00 \%$ of the positive inspections which attracted males of $C$. capitata; while, $15.00 \%$ occurred when $\mathrm{pH}$-level were less than 5.5. No males were captured in traps which had pH-levels more than 8.5 (Fig. 2).

With respect to total females and males of $C$. capitata, $79.25 \%$ of the positive inspections occurred when $\mathrm{pH}$-levels ranged between 5.5 and 8.5. On the other hand, $17.92 \%$ of the positive inspections were recorded when $\mathrm{pH}$-levels were less than 5.5; while, only $2.83 \%$ of inspections were recorded when $\mathrm{pH}$-levels were more than 8.5 (Fig. 2).

\section{Discussion}

The obtained results indicated that adding ammonium acetate, ammonium carbonate or di-ammonium phosphate to the protein-based attractant, Buminal increased its $\mathrm{pH}$-level which induced more attract ability for $C$. capitata adult females and males. These results came in the same line with those of El-Metwally (2018) and Ghanim (2018); who mentioned that adding ammonium acetate, ammonium carbonate or di-ammonium phosphate to the insecticidal protein-based bait, GF-120 increased its pH-level; and attractiveness to $C$. capitata and Bacrtocera zonata (Saunders). Also, the present study showed that Buminal $5 \%+3 \%$ of ammonium acetate, whereas $\mathrm{pH}$-levels ranged between 6.32 and 6.89 waqs the most attractive treatment for $C$. capitata. These findings are in agreement with Pinero et al. (2015) who found that adding ammonium acetate to protein baits potentially increased the bait's efficacy in attracting, monitoring and control of C. capitata. In other studies, Pelz et al. (2005) and Pelz-Stelinski et al. (2006) found that fruit flies spent more time surrounding the manipulated GF-120 bait by adding ammonium acetate; whereas, the higher levels of ammonium acetate in GF-120 can increase arrestment of foraging flies. Also, the current results are confirmed by El-Metwally (2018) and Ghanim (2018) who reported that addition of ammonium acetate to GF-120 bait improved its ability to attract $C$. capitata and B. zonata flies. Hemeida et al. (2017) reported that di-ammonium phosphate was more effective than ammonium acetate in enhancing the protein-based baits of Buminal, Agrinal and Amadene for attracting B. zonata adults. The variation between the present results and others may be attributed to the variation of fruit fly species and/or the concentrations of the used compounds.

The ability of Buminal to attract $C$. capitata was found to be basically dependent on the concentrations and $\mathrm{pH}$-levels with extrusive relationships between the attracted flies and pH-levels. These results are consistent with those of El-Gendy (2012), El-Metwally (2018) and Ghanim (2018); they mentioned that the attracted fruit flies (C. capitata and B. zonata) to baits that enhanced by ammonium compounds were found to be strongly dependent on concentration of ammonium compound and therefore on $\mathrm{pH}$ level. Ghanim (2018) added that the attractiveness of GF-120 baits enhanced by ammonium compounds was affected by pH-level more than concentrations. According to El-Gendy (2013) and Raga and Vieira (2015), adding borax makes the solution of ammonium compounds and protein food attractants more alkaline and therefore increases of released ammonia from the bait solution, and then increased the attracted B. zonata and C. capitata flies. Further, Mazor et al. (1987), Epsky et al. (1993) and Heath et al. (1994) found that elevation of the $\mathrm{pH}$ of the liquid commercial baits, Buminal, Naziman and Nulure increased their efficacy as baits for C. capitata and Anastrepha suspensa (Loew). 
The present study concluded that $C$. capitata preferred baits which had $\mathrm{pH}$-levels ranged between 5.5 and 8.5 and the highest attractive treatments were occurred between 6.32 and $8.29 \mathrm{pH}$. This could be due to higher release of ammonium at higher level of $\mathrm{PH}$ of protein bait. These results are confirmed by Paiva and Parra (2013), El-Metwally (2018) and Ghanim (2018); they mentioned the highest captures of C. capitata and B. zonata occurred with baits adjusted to a $\mathrm{pH}$ of a range from 7.00 to 8.5. On the other hand, C. capitata females were more responded to the increase of $\mathrm{pH}$ and concentrations attractants in comparison with males. Similar results were obtained by El-Metwally (2018) and Ghanim (2018), who mentioned that females of $C$. capitata and B. zonata were more responded to the increase of $\mathrm{pH}$ in GF-120 preparations. On the other hand, when $\mathrm{pH}-$ levels were less than 5.5 or higher than 8.5, there were few numbers of attracted $C$. capitata flies in traps. These results are supported by IAEA (2003) who reported that fewer fruit flies are attracted to the mixture as the $\mathrm{pH}$ becomes more acidic.

Also, the obtained results showed that Buminal alone or enhanced by ammonium compounds attracted females more than males of $C$. capitata. These results are in agreement with those obtained by Yee (2007), Hemeida et al. (2017), El-Metwally (2018) and Ghanim (2018); who reported that females of Rhagoletis pomonella (Walsh), B. zonata and $C$. capitata were responsive to the protein-based baits more than males. Yee (2007) added that the lures affected the sexes similarly in terms of relative responses. Also, Epsky et al. (1993), Heath et al. (1994), Abd El-Kareim et al. (2008), Moustafa and Ghanim (2008), El-Metwally (2012), El-Gendy (2012 and 2013) and Ghanim et al. (2014) reported that ammonium compounds and protein-biased baits attracted females of fruit flies more than males. According to Rousse et al. (2005), when Bactrocera cucurbitae (Coquillet) flies were protein starved, females were caught numerically more than males in traps baited with food attractants. Females of fruit flies require a source of protein to complete egg maturation; so, this requirement is probably the main cause for the strong attraction of females towards decomposing proteinaceous substances (Epsky et al., 2014; Pinero et al., 2015; Hemeida et al., 2017; El-Metwally, 2018; Ghanim, 2018).

\section{Conclusion}

The present study concluded that $C$. capitata preferred baits which had $\mathrm{pH}$-levels ranged between 5.5 and 8.5 and the highest attractive treatments were occurred between 6.32 and $8.29 \mathrm{pH}$. Additional studies should be done on the relationships between $\mathrm{pH}-\mathrm{lev}-$ els of attractants and their ability to attract different species of fruit flies based on the release rate of ammonium and $\mathrm{pH}$ of protein baits solution.

\section{Acknowledgements}

The authors wish to thank Dr. Reda A. El-Sharkawy, Plant Protection Research Institute, Agricultural Research Center; for determining $\mathrm{pH}$-degrees of the present study. 


\section{Literature}

Abd El-Kareim, A. I., Shanab, L. M., El-Naggar, M. E. and Ghanim, N. M. (2008): Response of peach fruit fly, Bactrocera zonata (Saunders) (Diptera: Tephritidae) to some ammonium compounds as olfactory stimulants. J. Agric. Sci. Mansoura Univ. 33, 8965-8973.

Barzman, M., Bàrberi, P., Birch, A. N. E., Boonekamp, P., Dachbrodt-Saaydeh, S., Graf, B. and Lamichhane, J. R. (2015): Eight principles of integrated pest management. Agronomy for Sustainable Development 35, 1199-1215. https://doi.org/10.1007/s13593-015-0327-9.

Bayoumy, M. H. and El-Metwally, M. M. (2017): Daily flight activity rhythms of the peach and Mediterranean fruit flies using sexual and olfactory attractants. Acta Phytopathol. et Entomol. Hung. 52, 227-244. DOI: 10.1556/038.52.2017.022.

Borge, M. N. and Basedow, T. (1997): A survey on the occurrence and flight period of fruit fly species (Diptera: Tephritidae) in a fruit growing area in southwest Nicaragua. Bull. Ent. Res. 87, 405-412.

CoHort Software (2004): CoStat. www.cohort.com Montery, California, USA.

El-Gendy, I. R. (2012): Evaluating attractency of some protein derivatives for the Mediterranean fruit fly, Ceratitis capitata (Wiedmann) and the peach fruit fly, Bactrocera zonata (Saunders). Int. J. Agric. Res. doi: 10.3923/ijar.2012.

El-Gendy, I. R. (2013): Response of peach fruit fly, Bactrocera zonata (Saunders) (Diptera: Tephritidae), to synthetic food-odor lures and extent the effect of $\mathrm{pH}$ on attracting the fly. J. Entomol. 10, 136-146.

El-Metwally, M. M. (2012): Response of the olive fruit fly, Bactrocera oleae Rossi to some ammonium compounds and certain food attractants under field conditions in olive orchards. J. Plant Prot. Pathol. Mansoura Univ. 3, 491-502.

El-Metwally, M. M. (2018): Enhancing the attraction efficiency of GF-120 for the Mediterranean fruit fly, Ceratitis capitata (Wied.) by adding some ammonium compounds. J. Plant Prot. and Path., Mansoura Univ. (In press).

Epsky, N. D., Heath, R. R., Sivinski, J. M., Calkins, C. O., Baranowski, R. M. and Fritz, A. H. (1993): Evaluation of protein bait formulations for the Caribbean fruit fly (Diptera:Tephritidae). Florida Entomologist 76, 626-635.

Epsky, N. D., Kendra, P. E. and Schnell, E. Q. (2014): History and development of food-based attractants. In: T. Shelly, N. Epsky, E. B. Jang, J. Reyes-Flores and R. I. Vargas (eds): Trapping and the Detection, Control, and Regulation of Tephritid Fruit Flies: Lures, Area-wide Programs, and Trade Implications. Springer, The Netherlands, pp. 75-118.

Franco, J. C., Garcia-Marí, F., Ramos, A. P. and Besri, M. (2006): Survey on the situation of citrus pest management in Mediterranean countries. IOBC/WPRS Bull. 29, 335-345.

Ghanim, N. M. (2012): Responses of Ceratitis capitata Wiedemann and Bactrocera zonata (Saunders) to some weather factors and fruit ripening in persimmon orchards. Bull. Ent. Soc. Egypt, 89, 201-214.

Ghanim, N. M. (2016): Occurrence and competition between males of Bactrocera zonata (Saunders) and Ceratitis capitata Wiedemann (Diptera: Tephritidae) on grapes and guava at Dakahlia governorate, Egypt. Egypt. J. Agric. Res. 94, 795-808.

Ghanim, N. M. (2017): Population fluctuations of the Mediterranean fruit fly, Ceratitis capitata (Wiedemann) with respect to some ecological factors in peach orchards. J. Plant Prot. and Path., Mansoura Univ. 8, $555-559$.

Ghanim, N. M. (2018): Improving the efficiency of GF-120 baits in attracting Bactrocera zonata by adding ammonium compounds with particular emphasize on $\mathrm{pH}$ level. (Under publication).

Ghanim, N. M. and Moustafa, S. A. (2009): Flight activity of Mediterranean fruit fly, Ceratitis capitata Wiedemann in response to temperature degrees and relative humidity at Dakahlia governorate. Bull. Ent. Soc. Egypt, 86, 209-221.

Ghanim, N. M., Abdel-Baky, N. F., Al-Doghairi, M. A. and Fouly, A. H. (2014): Evaluation of some ammonium compounds as olfactory stimulants for ziziphus fruit fly, Carpomya incompleta (Diptera: Tephritidae) in Christ's thorn orchards at Qassim, Saudi Arabia. J. Plant Prot. and Path., Mansoura Univ. 5, 367-377.

Hanafy, A. H., Awad, A. I. and Abo-Sheasha, M. (2001): Field evaluation of different compounds for attracting adults of peach fruit fly Bactrocera zonata (Saunders) and Mediterranean fruit fly, Ceratitus capitata (Wied.) in guava orchards. J. Agric. Sci. Mansoura Univ. 26, 4537-4546. 
Hashem, A. G., Mohamed, M. S. A. and El-Wakkad, M. F. (2001): Diversity and abundance of Mediterranean and peach fruit flies (Diptera: Tephritidae) in different horticultural orchards. Egypt. J. Appl. Sci. 16, 303-314.

Hassanein, S. S. M., El-Fishawi, A. A., El-Hakim, A. M. and Mosallam, A. Z. (1995): Latent effect of some pesticides on certain biological aspects of Ceratitis capitata (Wied.) and its chemical control. Egypt. J. Agric. Res. 73, 155-165.

Heath, R. R., Epsky, N. D., Bloem, S. and Bloem, K. (1994): pH effect on the attractiveness of a corn hydrolysate to the Mediterranean fruit fly and several Anastrepha species (Diptera: Tephritidae). J. Econ. Entomol. 87, 1008-1013.

Hemeida, I. A., Ghanim, N. M., Mosallam, A. M. Z., EL-Shabrawy, H. A. and Metwaa, B. M. (2017): Enhancement of some protein-based baits for attracting Bactrocera zonata (Diptera: Tephritidae) by adding ammonium compounds. Egypt. Acad. J. Biolog. Sci. 10, 149-162.

IAEA, (2003): Trapping Guidelines for Area-Wide Fruit Fly Programmes, Joint FAO/IAEA Division, Vienna, Austria. http://www-naweb.iaea.org/nafa/ipc/public/trapping-web.pdf

Joachim-Bravo, I. S., Guimarães, A. N. and Magalhães, T. C. (2001): Influência de substâncias atrativas no comportamento alimentar e na preferência de oviposição de Ceratitis capitata (Diptera: Tephritidae). Sitientibus, Série Ciências Biológicas 1, 60-65.

Kaspi, R., Taylor, P. W. and Yuval, B. (2000): Diet and size influence sexual advertisement and copulatory success of males in Mediterranean fruit fly leks. Ecol. Entomol. 25, 279-284.

Lance, D. R. (2014): Integrating tephritid trapping into phytosanitary programs. In: T. Shelly, N. Epsky, E. B. Jang, J. Reyes-Flores and R. Vargas (eds): Trapping and the Detection, Control and Regulation of Tephritid Fruit Flies. Springer, The Netherlands, pp. 559-588.

Liquido, N. J., Shinoda, L. A. and Cunningham, R. T. (1991): Host plants of the Mediterranean fruit fly, Ceratitis capitata (Wiedemann) (Diptera: Tephritidae): An annotated world review. Miscellaneous publication 77. Entomol. Soc. Amer. Lanham. MD.

Mazor, M., Gothilf, S. and Galun, R. (1987): The role of ammonia in the attraction of females of the Mediterranean fruit fly to protein hydrolysate baits. Ent. Exp. App. 43, 25-29.

Moustafa, S. A. and Ghanim, N. M. (2008): Some ammonium compounds as olfactory stimulants for Mediterranean fruit fly, Ceratitis capitata Wiedemann (Diptera: Tephritidae). J. Agric. Sci. Mansoura Univ. 33, 8965-8973.

Moustafa, S. A., Ghanim, N. M. and Shawer, D. M. (2014): Presence of Ceratitis capitata Wiedemann and Bactrocera zonata (Saunders) in apple orchards at Dakahlia governorate, Egypt. Bull. Ent. Soc. Egypt, 91, 149-161.

Paiva, P. E. B. and Parra, J. R. P. (2013): Hydrogen ionic potential (pH) of the attractant, trap density and control threshold for Ceratitis capitata (Diptera: Tephritidae) on Hamlin oranges in Sao Paulo central region, Brazil. Revista Brasileira de Fruticultura 35, 464-470.

Papadopoulos, N. T. (2014): Fruit fly invasion: historical, biological, economic aspects and management. In: T. Shelly, N. Epsky, E. B. Jang, J. Reyes-Flores and R. Vargas (eds): Trapping and the Detection, Control and Regulation of Tephritid Fruit Flies. Springer, the Netherlands, pp. 219-252.

Pelz, K. S., Isaacs, R., Wise, J. C. and Gut, L. J. (2005): Protection of fruit against infestation by apple maggot and blueberry maggot flies (Diptera: Tephritidae) using compounds containing spinosad. J. Econ. Entomol. 98, 432-437.

Pelz-Stelinski, K. S., Gut, L. J. and Isaacs, R. (2006): Behavioral responses of Rhagoletis cingulata (Diptera: Tephritidae) to GF-120 insecticidal bait enhanced with ammonium acetate. J. Econ. Entomol. 99, 1316-1320.

Pinero, J. C., Souder, S. K., Smith, T. R., Fox, A. J. and Vargas, R. I. (2015): Ammonium acetate enhances the attractiveness of a variety of protein-based baits to female Ceratitis capitata (Diptera: Tephritidae). J. Econ. Entomol. 108, 694-700.

Raga, A. and Vieira, S. M. J. (2015): Attractiveness of corn steep liquor plus borax to fruit fly (Diptera: Tephritidae) under field cages. Arquivos do Instituto Biologico (Sao Paulo), 82 unpaginated.

Rousse, P., Duyck, P. F., Quilici, S. and Ryckewaert, P. (2005): Adjustment of field cage methodology for testing food attractants for fruit flies (Diptera: Tephritidae). Ann. Entomol. Soc. Am. 98, 402-408.

White, I. M. and Elson-Harris, M. M. (1992): Fruit Flies of Economic Significance: Their Identification and Bionomics. CAB International, Wallingford, Oxon, UK, 601 p. 
and attraction of the mediterranean fruit fly

Yee, W. L. (2007): Attraction, feeding, and control of Rhagoletis pomonella (Diptera: Tephritidae) with GF-120 and added ammonia in Washington state. Fl. Entomol. 90, 665-673.

Yee, W. L. and Landolt, P. J. (2004): Responses of apple maggot (Diptera: Tephritidae) to ammonium hydroxide lures. Can. Entomol. 136, 139-142.

Yuval, B., Maor, M., Levy, K., Kaspi, R., Taylor, P. W. and Shelly, T. E. (2007): Breakfast of champions or kiss of death? Survival and sexual performance of protein fed, sterile Mediterranean fruit flies. Fl. Entomol. 90, 115-122. 
